\title{
The Indian Occupied Kashmir Dispute: A Legal Analysis in purview of United Nations Resolutions
}

\author{
Dr. Rao Qasim Idrees \\ Assistant Professor \\ School of Law, University of Gujrat, Pakistan \\ qasim.rao@uog.edu.pk \\ Dr. Muhammad Imran \\ Assistant Professor \\ College of Law, Government College University Faisalabad \\ m.imran163.adv@gmail.com \\ Tahir Jamil \\ LLM, School of Law \\ University of Gujrat \\ 18036024-019@uog.edu.pk
}

\section{Abstract}

Kashmir is an uncontrollable conflict between the two South Asian countries: India and Pakistan. Since 1989 the people of Kashmir have faced a massive violation of human rights committed by Indian forces. The United Nations resolutions strengthened the Kashmiri's movement of freedom. However, it is also a reality that, somehow and somewhere, the UN had failed in the Kashmir dispute in order to give the implementation to its resolutions. The Kashmir issue is complicated but could have been resolved if the UN had taken its responsibility with true letter and spirit. Recently, the Indian government changed the status of Kashmir by the abolishment of Article 370 and 35A, and also passing a Bill in August 2019, further makes the situation more difficult in Kashmir. In this situation, it is pertinent to mention here that Indian occupied Kashmir is a disputed issue in the light of UNSC resolutions between two south Asian countries. The current research is based upon descriptive and historical methodology and the facts and results are provided as per the legal analysis of the current situation of Indian occupied Kashmir. Finally, this 
research concludes that India cannot solve the Kashmir dispute through revocation of Article 370 and 35A of the Indian constitution provisions about the status of Kashmir, and also not use of force; the Kashmir dispute can only be resolved according to the Resolution adopted by the United Nations Commission for India and Pakistan on 13 August 1948.

Keywords: Human Rights, Indian Constitution Article 370 \& 35A, Kashmir Dispute, United Nations Resolutions

\section{Introduction and History}

(Abbasi, 2020) argues that the Kashmir conflict has been a continuous source of apprehension among two major nuclear rivals, India and Pakistan. The Indian Occupied Kashmir includes over ten million people in the Kashmir Valley of Jammu and Ladakh. (Abid, 2016) states that the dispute in Kashmir began with Maharaja Gulab Singh in 1846. It was achieved through the famous Amritsar Treaty. His empire passed to his successor after Gulab Singh's death and was subsequently dominated by Maharaja Hari Singh until 1949. Those rulers became notorious for being dictatorial and authoritarian in 1931, and the majority of Muslims were also angry and generalized. The Hindu prince of Kashmir, Maharaja Hari Singh, entered India without respect to the wish of the people since the Kashmir majorities were Muslim India in collusion with the Kashmir.

One opinion is that India annexed Kashmir to justify its acts by pressuring the Maharaja to sign accession documents. After that accession, India has been occupying Kashmir's occupied region and consistently abusing the human rights of the citizens of Kashmir. Even the mobilization of security forces provides women with serious intensity. Women were treated and violated by powers during the hunt. (Ahmad, 2017) analyses that since the Indian government put a curfew on Kashmir valley, the privileges to freedom of speech are also being denied, news of abuse, assassination, abduction, rape against Kashmiri people, as well as prohibiting the residents of Kashmir from offering their religious duties and rights, are not being made public because of the military. In this installation, Kashmir began battling for the right to self-determination against the Indian conquest. 
(Aijazi, 2020) states that more than 60 years have elapsed since the Kashmir movement started seeking constitutional rights and the right to selfdetermination on the agenda of the UN Resolution of 13 August 1948 and the 5th of January 1949. In these resolutions, approved by the United Nations Committee for India and Pakistan, the Pakistani side notes that Kashmiri should have the right of self-determination under Article 1(2) of the United Nations Charter. It would also stress how the citizens of this country have been silenced for the armed forces' misuse. (Ali, 2020) informs that the residents of Kashmir are animosity violations and willing to see peaceful Kashmir without dispute of infringement of human rights. The main role in Kashmir is contested in settling the disagreement in compliance with the UN settlement.

Moreover, disputes in Kashmir exist, an exceedingly ancient controversy in foreign relations. The matter of Kashmir may have been fixed if the UN takes liability. On the other hand, though, mediation in Kashmir is a denial of third-party mediation by India. The link was further aggravated by a further Indian act of 5 August 2019 by revoking Article 370 and 35A of India's Constitution, which provided Jammu and Kashmir with special powers to allow it to have its constitution and to render it autonomous (B.M Association, 1992). Whereas Article 35A of the Constitution of India allowed Jammu and Kashmir State legislatures to identify permanent residents, it conferred on permanent residents' unique rights such as work opportunities and the right to purchase land. Today, however, the status of Jammu and Kashmir has modified through the abolition of these papers, and India has snubbed Kashmiri's privileges and enforced its curfew over four months. (Bajaj, 2011) states that following the revocation of Article 370 and $35 \mathrm{~A}$ of the Indian Constitutions, Pakistan has called for the internationalization of Indian massacres in Indian occupied Kashmir to be discussed on every international platform. In 2019 India also passed a Bill, "The Reorganization Jammu and Kashmir bill 2019" and that bill passed by the Indian parliament in Modi's government is against the will of the Kashmiri people and also against the international laws and covenant. Further in this research also discuss the bilateral agreement between Pakistan and India, resulting from the Shimla Agreement of July 1972. (Bali,2015) analyses that it was decided between Indian and Pakistan that both countries resolve all their matters, including the Kashmir dispute, through mutual consultation and negotiation, but India changed the original 


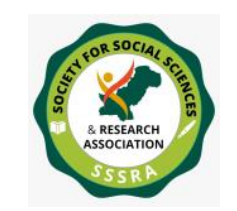

The Indian Occupied Kashmir Dispute...

status of Kashmir individually by repealing the special provision in the shape of two articles. In the 74th session of the United Nations general assembly in New York, the prime minister of Pakistan, Imran Khan, addressing the session of the United Nation and asked the world community to play their role to resolved the Kashmir dispute and also protected the fundamental rights of Kashmiri by Indian forces and government.

Further, on the groundbreaking ceremony of Kartarpur Corridor on 9th November 2019, the Prime Minister of Pakistan said, "Kashmir is not only a territorial issue but also an issue of humanity". India claimed their big democratic country in the world and also claimed the necessities and other fundamental rights to our state people, but in reality, just in Kashmir, India makes many laws at variance with human rights. The freedom of rights before the rule of life and the right to unlawful detention under Clause 4, 21, and 22 of the Indian Constitution, and sections 330 and 331 of the Indian Penal Code forbid torture. Chapter 5 of the Manual of Criminal Law allows for separate laws. Yet the Indian government's human rights practice in Jammu and Kashmir contradicted their guarantees. It is not false because if citizens in Kashmir assert the right of self-determination and other human rights. It is compulsory for all parties participating in the Kashmir dispute to uphold UN conventions and resolutions and to preserve costly human blood and, ultimately, the goal of UN creation for preserving international peace and preservation of human rights. The position of the United Nations has authorized a plebiscite that leaves the country to determine its political fate. India cannot personally settle the conflict over Kashmir by removing Article 370 and $35 \mathrm{~A}$ in the Indian Constitution, allowing for the Jammu-Kashmir special status.

\section{Enforcement of Human Rights in Indian occupied Kashmir}

(Chitkara, 1996) emphasises that the current condition in Kashmir and the region's past must be remembered. Kashmir was sold by the British in 1846 to Maharaja Gulab Singh. Maharaja Gulab Singh subsequently established himself as Kashmir's sole princely monarch. It was achieved through the popular recognition treaty. After the demise of Gulab Singh, his realm passed on to his supporters and eventually was governed until 1949 by Maharaja Hari Singh. In 1931, these kings became regarded as tyrannical 


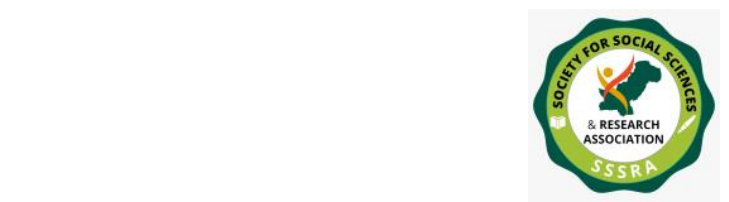

and authoritarian. The bulk of the Muslim community also witnessed rebellion and general instability.

It is pertinent to mention here about the unjust red cliff award because it's part of history about Kashmir accession of India. (Cook, 2012) states that the Redcliff award resulted in British revenge and shameful demarcation. It provided a large number of territories from provinces of Punjab. The province of Punjab was divided into four districts and three districts of Punjab having a Muslim majority population, but the British handed over all the Muslim states to India according to in Redcliff award. In this way, this excess allowed India a safe passage to Kashmir. During freedom, the princely states had the choice of entering or staying independent India or Pakistan; nevertheless, the existence of these States remained undecided and tension generated between India and Pakistan. Kashmir has a significant geographical role and borders with Tibet, China, Afghanistan, and Russia. It was a Muslim majority state, and citizens wished to enter Pakistan, but its chief Maharaja Hari Singh of the Hindu dynasty of Dogra decided to balance India.

The central government started to control the political structure in Kashmir valley after the Shimla Accord, 1972. (Deol, 2018) informs that in 1980 Islamization start penetrating in Kashmiri people rapidly. The Islamic content attracted the young generation are being disturbed in Kashmir valley that being Islamic awareness in Kashmir people, that was initially named as "Kashmir and Kashmiri" and "fight for freedom" that Islamic content educated the people of Kashmir and across anti-India sentiments in them because of Saudi pressure in 1979 and Islamic conference was held in Srinagar. After 1980 in Jhelum medical college, the purpose of these two conferences was to promote Islamic thoughts and socialism in Kashmir valley. The young and educated peoples of Kashmir did not contend with the weak political system in the valley, which gives rise the unemployment and frustration in the young generation. In 1986 Indian Prime Minister Rajiv Gandhi and Jammu and Kashmir chief minister Farooq Abdullah signed an accord in which the human rights violation and matter going through against the will of the young generation of Kashmir were fully enlightened. (Dobhal, 2009) states that there were basic reasons that belong to environmental insurgency. In the mean time in 1987, an inflexible election was held in which the Muslim united front MUF also participated. MUF 


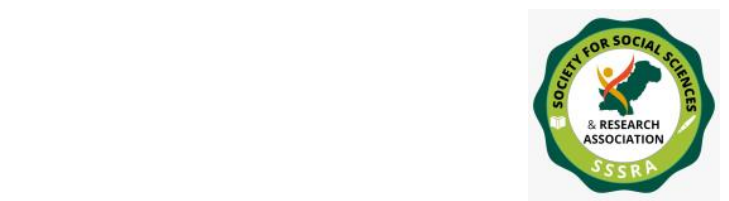

was in support of the freedom movement and the Islamic system. Leaders of MUF parties were playing a vital role in the political structure and peaceful democracy in the Kashmir valley, but the Indian security forces military arrested young Kashmir accusing them. They joined militant groups to take their revenge. Failure of democracy gives rise to the insurgency in the Kashmir valley, and human rights for the people of Kashmir become more difficult. (Duschinski \& Ghosh, 2017) argues that in 1988 freedom movement against the Indian military and administration started loudly, and the Indian military started arresting and torching the people of Jammu and Kashmir.

On December 8, 1989, here comes a turning point when Rabia Saeed's daughter of Mufti Muhammad Saeed was kidnapped and released by five prominent leaders of the Jammu and Kashmir liberation front (JKLF) was demanded her freedom. After this incident government of India contacted crackdown at a massive level, and after the resignation of Farooq Abdullah, all militant groups were banned, and right after that, the government of India enforced governor rules in Kashmir valley. (Ejaz, 2017) informs that on January 19, 1990, the sitting governor was replaced by the new governor Jag Mohan Malhotra, and on the first day of his governance, security forces open fire at innocent Kashmiri and martyred 53 innocent Kashmiri, and so many were injured. This massacre is famous as Gawked Massacre; resultantly, the insurgency suppressed the occupied Kashmir valley. After the appointment of Jag Mohan Malhotra as governor on January 19, 1990, a massive violation of the human rights of Kashmiri people and their massacre remains to continue till May 26, 1990. Every single Kashmiri was mantel and physically tortured and imprisoned to raise his voice for their right to self-determination. Security forces were deployed in the name of protection in the Kashmir valley to protect Kashmiri people, but in reality, they started to violate human rights at a massive level in Indian occupied Kashmir. Indian army and other security forces are violating not only the rights of Kashmiri people but also violating the international laws explicitly. For example, custodial death, extra-judicial execution, disappearances, security forces detain any Kashmiri without any arrest warrant and transfer them to tortured cell for torching them in so many brutal ways such as short circuit coal burn and fire burn.

\section{Conflict of Indian policy with Intentional Human Rights Laws}


(Gossman, 1993) states that in the name of public safety, the Indian government used to enact laws used to suppress the human rights of the people of Indian occupied Kashmir. Jammu and Kashmir's public safety Act 1978 is an excellent example of such acts. According to it, Indian forces can detain any person for three months without disclosing any reason for such detention and can also be transferred from one state to another without informing their families. Such detention may be extended to one year or two years.

\subsection{Terrorist and Disruptive Activities (prevention) Act 1987 (TADA)}

There is no freedom of speech or expression in the Kashmir valley. Any person arrested under this law shall be prosecuted in the camera after the consent of prosecution. There were two special courts in Srinagar and Jammu and Kashmir working under this Act, but now a day's only one court in Jammu and Kashmir is working, which is not enough bear the workload of two-state and people are facing hardship to have a free and fair trial.

\subsection{Armed Force Special Power Act 1990}

(Gupta, 2009) argues that Armed Forces Special Power Act, 1990 allows armed powers to avoid any activity with the aid of the civilian forces. While national and international experts have frequently appealed to abrogate the AFSPA, the Indian authorities have provided nothing to signal the abrogation or amending of this law in Jammu and Kashmir. In Jammu and Kashmir and other northeast India states, at least two judicial boards constituted by the Indian authorities. (Justice Jeevan Reddy Committee and Justice Santosh Hegde Committee) have called for the expulsion of AFSPA from India. UN Special Rapporteurs on extrajudicial and unlawful killings and abuse against women have called for the elimination during their country visits to India in 2012 and 2013 of AFSPA. The purpose of this act, the Central Government or the Governor can announce any area as a "troubled area" under Section 3. No rules are laid down for exercising this warning. It was held in Inderjit Barua V/S state of Assamthat. It could not be casual on the view of lack of legislative rules". Thus, it was exempted from the judicial analysis.

\subsection{Prevention of Terrorism Act (POTA)}


(Haq, 2018) informs that another Act which is an open infringement of human rights in the valley, as well as the national recognition of the citizens of India that the Indian Constitution or the universal norm may not justify such an act, includes four clauses of this act, which is an outright violation of human rights. (i) Detention without trial (ii) Confession before the police as evidence (iii) Denial of the public hearing (iv) Criminal offenses of lawful political nature and free expression the laws were widely criticized in India and the United Nations. Still, Hindu Federation, including Shive Senna and the other powers, sponsored these actions and shielded the unlawful acts of their armed foe because of the war between India and Pakistan. Other regulations have been passed or improved with adverse human rights interactions. According to the Foreign Committee on Legal Affairs, the judicial system in Kashmir is almost unreliable in coping with bail requests and not placing the citizens thrilling of the violations of the war on trial.

\section{Report of International Organizations on Human Rights Violation in Indian Occupied Kashmir}

(Haq, 2020) states that international organizations such as international human rights organizations, Human rights watch, Amnesty international, and physicians of human rights are continually reporting a violation of human rights in Indian occupied Kashmir. Those reports were published in two different periods, 1990 and 2003. These reports state about the human rights violation admitted in Indian occupied Kashmir. Firstly in 1996 human

rights watch Asia and secondly in 2004. European Parliament committee for foreign affairs in their reports mentioned that the Indian government is responsible for human rights violations of Kashmiri people, which includes the cases of severe violation like torture, disappearance, rape, and illegal detention. This violation is still happening in the valley till now; according to watch report, Indian authority admits minute violation of human rights by the security forces, and most cases are under investigation and interrogation, and also many officials were punished and suspended for violating human rights in Indian occupied Kashmir. Today in Indian occupied Kashmir, the international human rights organization is reporting violation of human rights at a massive level in the whole valley. Neither the Kashmiri people can move with their free will nor their rights of self-determination is being given to them. He who raises his voice for their right of self-determination is 


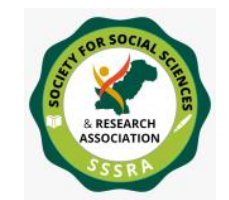

torched and detained and transferred to an unknown place under their socalled laws as most of the population in Kashmir is Muslims. Even the Kashmiri Muslims are restrained from performing their religious obligations. Today in Indian occupied Kashmir, the educational system is completely suspended, and the forces occupy most of the schools. Educational career of more than 1.5 million is at high risk. (Hussain, 2012) analyses that people of Indian occupied Kashmir have limited access to the hospital and other health facilities; security forces often obstruct Kashmiri even from approaching the hospital. In this scenario, the right to have good health and health facilities is being badly violated. Article 4, 21, and 22, of the Indian constitution, states that all are equal before the law and every citizen has the right to life and the right against arbitrary imprisonment; even Indian penal laws and specifically section 330 and 331 of the Indian penal code, refrain from torture, whereas chapter 5 describes its rules. But nowadays, if any Kashmiri raises his voice for freedom is brutally tortured and imprisoned in jail without any charge of information. Kashmiri people do not have any basic rights, and the right to life as other people are enjoying in different countries. The people of Indian occupied Kashmir are facing more sanction in the shape of lockdown nowadays. The departure of security forces is also a great danger for the women of the Kashmir valley. Security forces misbehave and maltreated women during search operations. Women are being raped frequently in the valley and tried to keep other people to slut their voices against the cruel behavior; the rape and torture cases in Kashmir valley are increasing every year. Those who raise his voice against the cruelty of the forces are torture and detained in the poisoned and sometimes tortured to death, and most of them are students of the valley.

\section{The Effects of Repealing Article 370 and $35 \mathrm{~A}$ of the Indian Constitution}

(Kanjwal, 2019) argues that the Indian Occupied Jammu and Kashmir are granted a separate status by Article 370 of the Indian Constitution in India, which is the major source of tension between India, Pakistan, and China. Article 370 grants Jammu and Kashmir special power to provide its constitution, state flag, and sovereignty concerning internal state administration. The constituent assembly of Jammu and Kashmir was allowed. After its creation, to revoke Article 370 altogether or to commend articles of the Indian Constitution for applying to the territory. After 


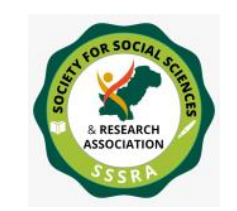

The Indian Occupied Kashmir Dispute...

consultation with the State Constituent Assembly, it defined the articles of the Indian constitution relevant to the state in 1954 by way of the presidential order. In comparison to other Indian nationals, this provision along with Article 35A, specifies that the residents of the Jammu and Kashmir state abide by a different collection of rules, including state basic rights and property rights as the acquisition of land in the Indian Occupied Kashmir is not allowed by Indian People until the abolition of Article 370.

(Kanungo, 2012) states that under several Indian National Congress parties, locally-elected municipal governments as well as central governments such as those of the National Conference between 1954 and 2011, Article 370 was used by India with the consent of the State Government to give Presidential Orders and expand the Indian Constitution to Jammu and Kashmir as well as to limit state sovereignty. The big explanation for the Kashmir controversy is these infamous past presidential directives in compliance with Article 370. (Khan, 2020) enunciates that the Kashmiri political leader Sumatra Bose explained the politics of the time between 1953 and 1963 when Bakshi Ghulam Muhammad was the Prime Minister of Jammu and Kashmir in these words: The Prime Minister remained Bakshi Ghulam Mohammed for ten years, until October 1963. A series of acts during his term strongly indicates a shared understanding between Bakshi and the Indian government which would allow him to precede a representative reckless government in Srinagar in exchange for facilitating IOK "integration" in New Delhi with India. It ends in the valley unlawfulness and pathos is of political structures in IOK in two respects and IOK attrition. (Khan, 2015) states that the 1954 Presidential order and subsequent orders "were the first move in abolishing the rule of Article 370" and "were unsuccessful and self government achieved (as needed under Article 370) with the "conspiracy" of a so-called IJK government consisting of a mixed community of New Delhi clients.

(Komath, 2020) argues that the Hindutva Indian Hindu association began saying that Jammu and Kashmir were a crucial part of India after the Indo and Pak split into religious terms. The same claim to integration and the same claim to Jammu and Kashmir inclusion are included in the Bhartia Janta Party manifesto in past polls, and the BJP promises the integration during the 2019 Indian general election campaign. In Lok Sabah, the BJP and its supporters, the lower house of the Indian Parliament, secured a 


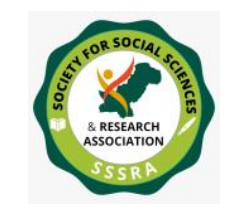

The Indian Occupied Kashmir Dispute...

sizeable vote. Through a presidential order on 5 August 2019, India replaced the order of 1954, rendering all aspects of the Indian constitution available in Jammu and Kashmir. Following the resolutions passed in both houses of the parliament, the President of India issued a further order on 6 August, declaring all the clauses of Article 370 except clause 1 to be inoperative.

\section{Revocation of the Special Status of Jammu and Kashmir}

(Kuitenbrouwer, 2003) states that on 5 August 2019, the Indian Government denied the special status of occupied Kashmir and restricted autonomy given to Jammu and Kashmir under Article 370 of the Indian Constitution a country managed by India as a province, with the broader Kashmir area being the cause of the conflict between India, Pakistan, and China. Not only did the Indian government abrogate Article 370, but it also cut off the means of contact in the Kashmir valley, which is a place of long-drawn separatist revolt. (Lone, 2018) states that many prominent Kashmiri leaders, including former Chief Minister Mehbooba Mufti, who declared the blackest day of India's democracy, have been taken into custody. The government official believes that such limitations are enforced to mitigate aggression and attempted to explain the removal as a key to give valley citizens greater access to government facilities such as reservation, right to inform, and right to education. The international organizations firmly criticize the abolition of Articles 370 and 35A of the Indian Constitution for Human Rights. The Kashmir Valley response is essentially dissimulated by cut-off contact.

Many Hindu nationalists in Kashmir appear to be working towards civil order and development. (Lone, 2018) states that the ruling party in India also supports the abrogation of these papers and other parties such as the Bhartia Janta Party, Bahujan Samaj Party, Aam Aadmi Party and Shiv Sena, Telegu Desam Party, among other parties. The groups opposing such an abrogation include the Jammu \& Kashmir National Conference, the Indian National Congress, the Trinamool Congress, Janata Dal (United), and the DMK (Democratic People's Party of Jammu and Kashmir). The decision was endorsed by citizens in Ladakh, the Buddhist group of Kargil. However, the Shia Muslim, forming the multiplicity of the populace in Ladakh, objected that the Indian President released an order under the jurisdiction of Article 370, superseding the new Presidential Order of 1954 and annulling all the rules of the state's self-government. The Indian Home Minister 


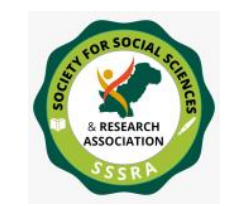

The Indian Occupied Kashmir Dispute...

proposed in the Parliament of India a reorganization bill to search for two separate countries in two combined regions ruled by the Lieutenant Governor and a unicameral legislature. The proposal to repeal the unique status under Article 370 and the bill for a State re-organization was discussed and adopted by the upper chamber of Rajya Sabha India on 5 August 2019. The lower house of parliament of Lok Sabha India discussed and approved the reorganization bill on 6 August following the resolution proposing the revocation. ( $\mathrm{Lu}, 1999)$ that the view of the constitutional specialist is split about whether the revocation is valid. Article 1 and Article 370 of the Indian Constitution refer to governments. In the same manner, the Federal Government has allowed the State Government to identify 'permanent residents, who were introduced by the Constitution in 1954, as given in Article 35A of the Constitution of India', article provides for access to land, scholarships, employment and so on.

In April 2018, the Supreme Court of India ruled that Article 370 had become permanent after the state constituent assembly ceased to exist. In reaction to this legal confrontation, while Article 370 has become "out of order" even though it is still present in the Constitution, the Indian government released the 2019 Constitutional Order (Application to Jammu and Kashmir), which superseded the 1954 Constitution (Application to Jammu and Kashmir) on August 5. Forty-seven presidential orders were released after 1954 from 11 February 1956 to 19 February 1994, with certain other clauses of an Indian constitution applicable to Indian Occupied Kashmir. All such orders were issued with the consent of a State government without a legislative assembly.

(Majid \& Hussin 2020) states that the presidential order of August 2019 notes that all the Articles of the Indian Constitution apply to Jammu and Kashmiri. The independent constitution of Jammu and Kashmir has been abolished. The Indian Parliament now works for the State Legislative Council, while the Governor is named directly by the Central Government. Therefore, the Home Minister of India has submitted a resolution [Rajya Sabha] in the upper house to support the President's necessary recommending that he should announce Article 370 out of order, which was subsequently debated and permitted by the Rajya Sabha on 5 August 2019 with 125 (67 percent) member, repealing the unique status given for by Article 370 and the draught law of state reorganization. 


\section{The Role of the UN against the Enforcement of Human Rights in Indian Occupied Kashmir}

(Soni, 2004) states that the Indian Prime Minister Pt. Nehru's assurances and promises remain unfulfilled as despite honoring those assurances made by, however, on 01.01.1948, the spokesperson of India at the United Nation P.P. Pillai, mail a letter to the President of United Nation Security Council that on 31.12.1947, convey a telegraphic communication from the Indian Government with lodging a complaint against Pakistan in United Nation Security Council. Pakistan vehemently opposed the complaint filed by India and submitted a written reply and also lodged a counter-complaint against India stating therein. Besides other things that India has attained the accession of Indian occupied Kashmir fraudulently, forcibly and through violence and large-scale carnage and looting and atrocities on Muslims of Indian occupied Kashmir have been carried out by the forces of Maharaja and Indian armed forces and by the non-Muslim subjects. Since the Indian Government claimed that the 1972 Shimla Agreement made all the previous Security Council resolutions obsolete, the Pakistani Government is making continuous efforts to call for these resolutions to be adopted.

The stance of the UN Secretary-General has been that it is only by resolution of the Security Council that UNMOGIP may be terminated; since such a decision was not made, UNMOGIP continued to work. In nature, the position of Kashmir remains unchallenged in the above resolution; by addressing the International Platforms of Occupied Kashmir, the Government of Azad Jammu and Kashmir has a significant function to play as statehood. (Stephen, 1999) informs that according to Article 13(b) of the ICC Charter, the authority of the Court can occur when the prosecutor is directed to the Court 'the condition in which one or more crimes [Article 5] seem to have been committed', even those involving non-State institutions. So, whatever the question of Kashmir's statehood, the Council is certainly allowed to refer the condition in occupied Kashmir to the ICC. It has not been achieved so far. The Council has the right to delay an audit or trial of the ICC. A postponement allows the Council to delay the event of the ICC. If the Council so agrees, the Court shall not be empowered for 12 months to begin or continue with its legal activities. This law was introduced because 'the search for justice often needs to give way to delicate political talks. Similar to considering the "interests of justice" under Article 53, it may be 


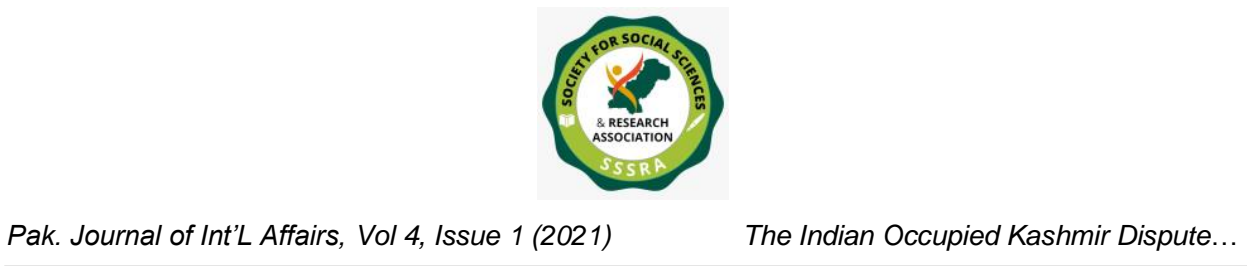

considered here that there is a greater possibility of stability in South Asia if an inquiry of the ICC and future proceedings is not launched.

(Qureshi, 2017) states that according to the manifesto of the United Nations, there are major to Matos that under lays the core alienation of the United States. The two said section is the enforcement of human rights and cop the way of agitation offered by any state. Furthermore, United Nations emphasises that the claimed territory of Kashmir occupied by the two nations (set-aside the Kashmir territory occupied by the china) India and Pakistan. The solutions of this dispute liaise in the public citation or referendum by Kashmiri people as they want to go with Pakistan or India. But there is one huge drawback as they settle the matter. They did not mention what kinds of sanctions each state has to undergo in noncompliance in the global context. India got the greatest corporate market, other than the United Nations non-state, to infiltrate in the said cause in favor of any two states. Nothing happened despite the world's biggest authorities decided the case. (Raman, 2004) finds that Pakistan and India had fought more than two wars for this territory, but there is a huge deadlock towards the solution in the capacity of the United Nations. (Recchia, 2019) argues that Pakistan wants to enforce decisions made by the United Nations resolutions against the plebiscite, right of self determination, and other human rights adopted on 21 April 1948. (Read, 2017) states that recently the Indian government amended its constitution unlawfully and infringed the human rights of millions of Kashmiri people.

\section{Conclusion}

Kashmiri people are being hassled and harassed by the Indian armed forces; on a routine basis, they violate the basic human rights in the valley. The Indian government has given a fully free hand to its forces. They are not accountable, so they are crushing basic human rights. At present, the situation of peace in Kashmir is extremely depressing and terrible. India should take some suitable steps to cut the Gordian knot of human rights violations in the Kashmir valley. Recently the Indian government repealed Article 370 and 35A of the Indian constitution, which is a direct attack on the sovereignty of the Kashmiri people, cut the race of the majority Muslim population of the valley. This attempt has increased the hatred in people's hearts, this has increased anarchy in the valley, and more people are now 
joining the movements of freedom fighters. The Kashmiri is not ready to succumb to the nasty wishes of the Indian atrocity and the feral forces. Indians claim Kashmir as their vital part, but the Kashmiri people have a different mindset. They want their right to make their own decisions without the pressure of the second party. They want their basic human rights completely without any contamination by the security forces. They ask the question to the world, will no one come and extinguish the fierce flames engulfing the valley? Right now, India is like a muzzled cat is a no-good mouser because of its wrong policies regarding the Indian occupied Kashmir; it should review its recent acts, i.e., Article 370 and 35A repealing. The international organization like UNITED NATIONS must play its role in the Kashmir issue, and it should put pressure on the Indian government. To stop violating human rights and to give Kashmiri their right to decide their merge, the UN must also try to implement its resolutions regarding Indian occupied Kashmir, as this issue has been the bone of contention between the two nuclear powers of South Asia; it should be solved according to the wishes of the Kashmiri people. To rethink their strategies and actions, they are doing in IOK; the government should restrain their forces from violating basic human rights. They must devise a system of accountability to punish those who assault the Kashmiri, and the victims must be compensated and satisfied. The Indian govt. should provide them the necessities of life like health, food, education, and equal rights to gain their trust and restrain the young generation from joining the militant groups. It should also support the valley's economy to provide more facilities to the people and enjoy their basic rights. It should also give the Kashmiri a free and fair referendum option to decide about their future because it is also their basic right as being a human. Peace within the state is the basic thing for any country to dream for a bright future, so the Indian government should show some seriousness on this issue to solve it according to the desire of the residents of the valley to clear its path for a bright tomorrow. 


\section{References}

Abbasi, M. I. (2020). Legitimacy of Kashmir's Liberation Struggle: Right to Self-Determination Under International Law. Strategic Studies, 40(1).

Abid, K. (2016). Post 9/11 and Pakistan's policy on Kashmir Issue. Center for Strategic and Contemporary Research (CSCR). http://cscr.pk/pdf/rb/RB\%20_Post\%20911\%20.pdf.

Ahmad, A., \&Najish, M. (2017). Balochistan Movement: Why India's Policy Took a Shift Towards Balochistan Under Narendra Modi Government. Health Issues, 39.

Aijazi, O. (2020). India Uses Coronavirus Pandemic to Exploit Human Rights In Kashmir. https://theconversation.com/india-uses-coronaviruspandemic-to-exploit-human-rights-in-kashmir-137682.

Ali, S. A. (2020). Demographic Changes: A Challenge to the Decolonization of Kashmir. People: International Journal of Social Sciences, 6(1).

Association, B. M. (1992). Medicine Betrayed: The Participation of Doctors In Human Rights Abuses. Zed Books.

Bajaj, M. (2011). Teaching to Transform, Transforming to Teach: Exploring the Role of Teachers In Human Rights Education In India. Educational Research, 53(2), 207-221.

Bali, P. S. (2015). Portrayal of Indian Army in Kashmir Media: An Analytical Study of Local Newspapers. International Journal of Media, Journalism and Mass Communications, 2(1), 51-57.

Chitkara, M. (1996). Human Rights: Commitment and Betrayal: APH Publishing.

Cook, R. J. (2012). Human Rights of Women: National And International Perspectives. University of Pennsylvania Press. 
The Indian Occupied Kashmir Dispute...

Deol, S. S., \& Ganai, R. A. (2018). Custodial Violence in Kashmir by The Indian Security Forces: A Spontaneous Consequence or A Deliberate Counter-Insurgency Policy? International Journal of Criminal Justice Sciences, 13(2), 370-384.

Dobhal, H. (2009). Manipur in the shadow of AFSPA: Independent people's tribunal report on human rights violations in Manipur. Socio Legal Information Cent.

Duschinski, H., \& Ghosh, S. N. (2017). Constituting The Occupation: Preventive Detention And Permanent Emergency In Kashmir. The Journal Of Legal Pluralism And Unofficial Law, 49(3), 314-337.

Ejaz, K. (2018). Human Rights Violations in Indian Held Kashmir (July 2016-July 2017). ICHRCP. Proceedings of International Conference on Human Rights: Challenges and Prospects 2

Gossman, P., \& Iacopino, V. (1993). The Crackdown in Kashmir: Torture of Detainees and Assaults on the Medical Community. Human Rights Watch.

Gupta, S. (2009). Human Rights among Indian Populations: Knowledge, Awareness and Practice. Gyan Publishing House.

Haq, I. (2018). Kashmir Conflict and Human Rights Violation. HONAI, $1(2)$.

Haq, I. (2020). Kashmir Conflict and the Advent of Torture: An Overview. Randwick International of Social Science Journal, 1(1), 42-52.

Hussain, M. M. (2012). Problem of Migrant Work force and protection of Human rights in Jammu \& Kashmir State. Indian J. Innovations Dev, l(9).

Kanjwal, H. (2019). Kashmir: A Case for Self-Determination. Brown J. World Affairs., 26, 253. 
The Indian Occupied Kashmir Dispute...

Kanungo, S. (2012). Echoes from Beyond the Banihal Kashmir: Human Rights and Armed Forces. Vij Books India Pvt Ltd.

Khan, R. M. (2015). Kashmir Dispute: A Legal Perspective. National Defence University Journal, 29(1).

Komath, A. (2020). State Behaviour at the Universal Periodic Review: An Examination of India's Third Review at the United Nations Human Rights Council. India Quarterly, 76(2), 185-206.

Kuitenbrouwer, M. (2003). Colonialism and human rights. Indonesia and the Netherlands in comparative perspective. Netherlands Quarterly of Human Rights, 21(2), 203-224.

Lone, F. N. (2018). Incorporation of Kashmir into the Indian Union: An International Assessment on Human Rights and Democratic Government. In Historical Title, Self-Determination and the Kashmir Question (pp. 239-314): Brill Nijhoff.

Lu, S.-P. (1999). Corporate Codes of Conduct and the FTC: Advancing Human Rights Through Deceptive Advertising Law. Columbia Journal of Transnational Law, 38, 603.

Majid, D. A., \& Hussin, D. M. (2020). Kashmir: A Conflict between India and Pakistan. South Asian Studies, 31(1).

Qureshi, W. A. (2017). Water as a Human Right: A Case Study of the Pakistan-India Water Conflict. Penn State Journal of Law and International Affairs. 5, 374.

Raman, A. (2004). Of Rivers and Human Rights: The Northern Areas, Pakistan's Forgotten Colony in Jammu and Kashmir. International Journal on Minority and Group Rights, 11(1-2), 187-228.

Read, M. F. The Kashmiri War: Human Rights and Humanitarian Law. http://www.cssforum.com.pk/css-compulsory-subjects/pakistanaffairs/7042-kashmiri-war-human-rights-humanitarian-law-1996a.html. 
Recchia, F. (2019). Contentious Memories. Territorial Control and the Creation of Heritage In Indian-Occupied Kashmir. Quaderni Storici, 54(2), 353-370.

Soni, S. K. (2004). UN Sub-Commission on Human Rights (53rd Session): A Report. Himalayan and Central Asian Studies, 8(4), 55.

Sripati, V. (2000). India's National Human Rights Commission: A Shackled Commission. The Boston University International Law Journal, 18, 1.

Stephen, L. (1999). The Construction of Indigenous Suspects: Militarization and the Gendered and Ethnic Dynamics of Human Rights Abuses In Southern Mexico. American Ethnologist, 26(4), 822-842. 